\title{
Energy Taxes as a Signaling Device: An Empirical Analysis of Consumer Preferences *
}

\author{
Tarek Ghalwash \\ Department of Economics, Umeå University \\ SE-901 87 Umeå, Sweden
}

\begin{abstract}
This paper presents an econometric study dealing with household demand in Sweden. The main objective is to empirically examine the differences in consumer reaction to the introduction of, or the change, in environmental taxes. Main focus is on environmental taxes as a signaling device. The hypothesis is that the introduction of an environmental tax provides new information about the properties of the directly taxed goods. This in turn may affect consumer preferences for these goods, hence altering the consumption choice. The result from the econometric analysis shows that all goods have negative own-price elasticities, and positive income elasticities. Concerning the signalling effect of environmental taxes the results are somewhat ambiguous. The tax elasticity for energy goods used for heating seems to be significantly higher than the traditional price elasticity, whereas the opposite seems to be the case for energy goods used for transportation.
\end{abstract}

Keywords: Household demand; energy tax; tax elasticities; emissions.

JEL Classification: D12; H31; Q41.

\footnotetext{
* I would like to thank Runar Brännlund, Kurt Brännäs and Jonas Nordström for helpful comments and suggestions. Research grants from FORMAS and Riksbankens Jubileumfond are gratefully cknowledged.
} 


\section{Introduction}

The main objective of this paper is to empirically examine consumer reactions as a response to the introduction of, or the change in, environmental taxes for different groups of commodities. Understanding consumer response to environmental taxes for different commodities is believed to be critical to the environmental policy makers.

One of the premises implied in this study is that the changes in consumer prices, as a result of changes in environmental taxes, may send a different signal to the consumer compared with other changes in consumer prices, such as changes in producer price. In addition, this assumed difference in the signalling effect of the changes in environmental taxes, compared to changes in the producer price, may also differ between different commodities (Berkhout, Carbonell and Muskens, 2004). ${ }^{1}$

Over the last decade and, particularly, after the framework Convention on Climate Change of 1992, many OECD countries have considered the introduction of "Green Tax Reforms" aimed at reducing the emission of green house gases. The reduction is usually used to measure the effectiveness of environmental taxes (OECD, 2000). OECD (2003) emphasizes the need for more research that examines the magnitude of the behavioral response of consumers to environmental taxes once they have been introduced. Such behavioral response is considered to be a necessary precondition for the correct implementation of different instruments of any environmental policy. For a better understanding of this behavioral response, it is essential to empirically examine consumer reactions to the introduction of, or change in, environmental taxes on different categories of commodities.

Behavioral response to environmental taxes can be estimated ex ante (predicted value) or ex post (actual values). The latter approach concentrates on the absolute reduction in consumption caused by the introduction or the increase of an environmental tax in a specific country at a specific time (Agnolucci, 2004). The ex ante approach uses econometric methods to estimate price elasticities, which, with precaution, are used to

\footnotetext{
${ }^{1}$ The signalling effect may not be due to the tax change itself, but rather the tax change comes in a combination with information and campaigns, which alters consumer preferences. For an analytical analysis of the signalling effect in tax policy, see for example, Barigozzi and Villeneuve (2004).
} 
predict behavioural responses to environmental taxes (Garcia-Cerruti, 2000; Halvorsen and Larsen, 2001).

In this paper, we formulate and estimate an econometric model for non-durable consumer demand in Sweden that utilises macro data. The system of demand equations is derived assuming cost-minimising households. The employed model is essentially a three-stage budgeting model with aggregate data from the Swedish National Accounts. In the first stage it is assumed that the household determines how much to spend on non-durable goods and how much to spend on durable goods (including savings). In the second stage it is assumed that the household allocates its total expenditure for nondurable goods on different non-durable commodity aggregates, or groups. Given the allocation on each non-durable commodity group, households in the third stage allocate their group expenditures on the various goods within the group. Our model is based on Deaton \& Muellbauer's (1980) almost ideal model (AIDS).

Specific in our modelling approach is the hypothesis of taxes as a signalling device. To account for this the consumer price is divided into a producer price part and a tax part. Given this partition, it enables us to estimate separate effects; a producer price effect and a tax effect. We also want to conduct tests of structural stability of the demand system for the entire sample period. It is important to check the stability of the model, since if it is unstable, it will be difficult to interpret the regression results.

The rest of this paper is structured as follows. In Section 2 we illustrate the design and purpose of the energy and environmental taxes introduced in Sweden. Section 3 describes the demand system, the data, as well as the estimation and test approach. Section 4 discusses the results. Finally in Section 5 we draw some conclusions.

\section{Energy and environmental taxation in Sweden.}

Environmental effects caused by energy generation and consumption are significant because of the widespread use of fossil fuels in the economic system. The magnitude of these effects is of concern, particularly in the case of climate change, but also due to other external costs related to fossil fuel use. 
Sweden has used taxes on energy since 1929, when a tax on gasoline was introduced. Electricity has been taxed since 1951, followed by a broadening of energy taxes in 1957. The motivation underlying these taxes was purely fiscal. Propelled by the global energy crisis in the 1970s; energy taxes were increasingly motivated by a desire to discourage consumption of fossil fuels. Thus, increased tax on oil products were coupled with a significant expansion of electricity supply in order to promote a different profile of energy consumption.

In the eighties, environmental concerns entered the discussion, manifested by the introduction of a tax differentiation of leaded gasoline in 1986. This was followed by the Environmental Tax Commission that recommended a rich array of environmental taxes in their proposal. New primarily environmental taxes, introduced in the 1991 tax reform, include a carbon dioxide tax on fossil fuel, and a sulfur tax on coal and oil. In addition, the VAT has been extended to all fuels, and a nitrogen dioxide tax is charged on emissions from large combustion plants (Brännlund and Kriström, 1997). Another green tax reform was discussed with the appointment of the Swedish "Green Tax Commission” (SOU 1997:11). The Green Tax Commission's main objective was to analyze the potential of fiscally neutral green tax reforms. The prospects in mind were that there may exist a “double dividend” (Brännlund and Nordström, 1999). ${ }^{2}$

This idea of a green tax swap was decided upon during spring 2000. It was decided that a switch from taxes on labour to environmental taxation amounting to 30 billion SEK will be carried out during the following 10 years. The main taxes considered are the $\mathrm{CO}_{2}$ tax and the energy tax on electricity.

The development of the general energy tax, as a share of consumer price, is displayed Figure 1. Here we can see that the tax on oil for heating has increased from approximately $10 \%$ of the consumer price in 1980 , to approximately $50 \%$ in 2002 . The tax on electricity shows a similar pattern.

\footnotetext{
${ }^{2}$ The "double dividend" will not be discussed in this work. For a review of this issue, see for example, Bovenberg (1999) and Schöb (2003).
} 


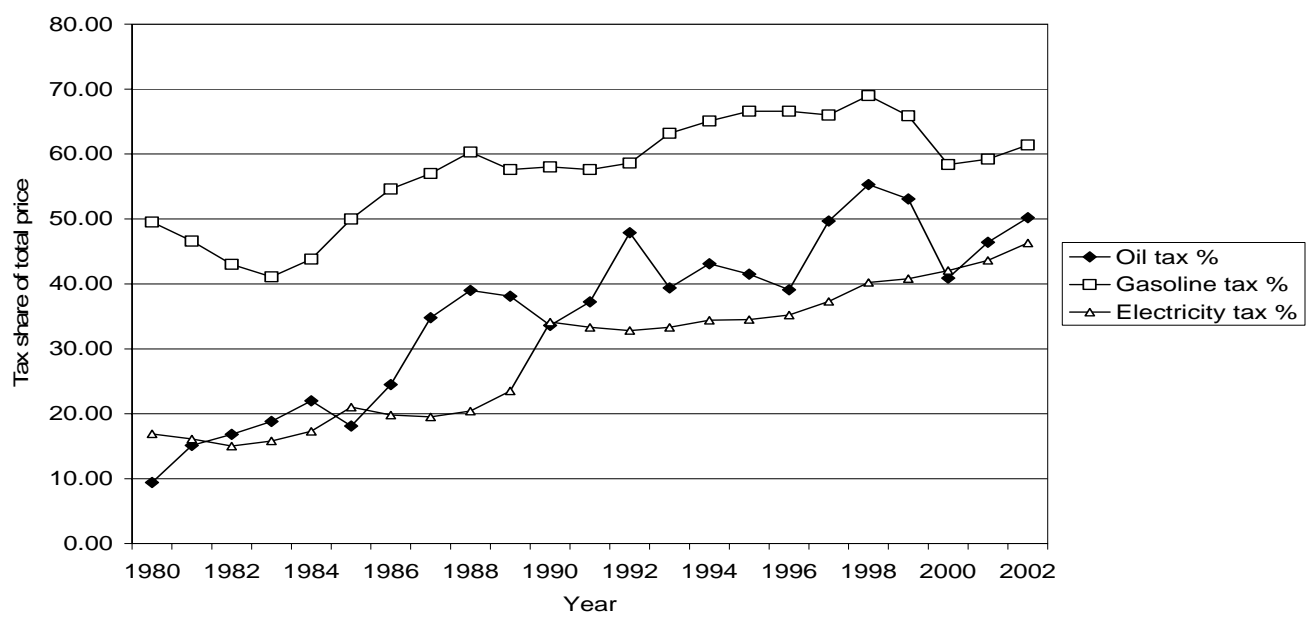

Figure1. Energy tax as a share of total price in Sweden, 1980-2002.

\section{The model}

In this section we formulate the demand system for non-energy and energy goods. We assume that consumers follow a three-stage budgeting process. In the first stage, the household decides on its leisure consumption, savings and investments (durable consumer goods). In the second stage, the household determines, given its total budget, how much to spend on food, heating, transports, and other goods. In the third stage, the household allocates resources within each of these groups. For, example, given a specific amount of money to be spent on transports, the household determine how much that should be allocated to expenditure on gasoline, car maintenance, and public and other transport. In the same manner the household determines in the third stage how to use its budget for heating. In this case the household can choose between electricity for heating, oil for heating or district heating. Our main objective is to model and estimate household choices in the second and third stage, with particular reference to energy taxes.

Demand function estimates are also very useful as they provide us with income and price elasticities. Consumers response to income and changes is required for the design of many different policies; For example, policy design for indirect taxation and subsidies requires knowledge of the response for taxable commodities and services (Deaton, 1980). Such knowledge would normally be obtained by the analysis of time series data on demand of commodities, prices, and income. 
We use the Almost Ideal Demand System (AIDS), first derived by Deaton and Muellbauer (1980). The advantages of this system are well known. It gives an arbitrary first order approximation to any demand system, satisfies the axioms of choice exactly, and is simple to estimate.

The Almost Ideal Demand System (AIDS) assumes that consumer preferences fall within the PIGLOG (price-independent generalized logarithmic) class so that exact aggregation over consumers is possible. In the AIDS model the budget share on a specific commodity, or group of commodities, in relation to full expenditure, can be written as:

$$
w_{i}=\alpha_{i}+\sum_{j} \gamma_{i j} \ln p_{j}+\beta_{i} \ln (Y / P)
$$

where $w_{i}$ is the budget share for $\operatorname{good} i, p_{j}$ is the price for $\operatorname{good} j, Y$ is total expenditure on non-durable goods, $P$ is the consumer price index, and the parameters to be estimated are $\alpha, \gamma$, and $\beta$. The consumer price index, $P$, is defined as Stone's price index, which is expressed as:

$\ln P=\sum_{j} w_{j} \ln p_{j}$

In order to analyse the difference in the signalling effect of the changes in environmental taxes compared to changes in the producer price, we have to separate the consumer price into a producer price part and energy tax part:

$$
p_{j}=\bar{p}_{j} \cdot \tau_{j}
$$

where $p_{j}$ is the consumer price index for energy good $j, \bar{p}_{j}$ the producer price index for energy good $j$, and $\tau_{j}$ is the energy tax index, which represents the environmental tax for specific good. The energy tax index has been calculated by dividing the observed consumer price index on observed producer price index, which can be represented by the following equation: 
$\tau_{j}=\frac{p_{j}}{\bar{p}_{j}}$

Allowing for a difference in signalling effects, equation (1) can now be written as:

$w_{i}=\alpha_{i}+\sum_{j} \gamma_{i j} \ln \left(\bar{p}_{i}\right)+\sum_{j} \tilde{\gamma}_{i j} \ln \tau_{i}+\beta_{i} \ln (Y / P)$

The budget share equation (5) includes two parameters representing the consumer price, the first one, $\gamma_{i j}$, is the coefficient for the producer price index and the other, $\tilde{\gamma}_{i j}$, is the coefficient for energy taxes index. In this case we can capture the effect of energy taxes on the consumer behaviour and see if there is any difference between the parameters of energy taxes and the parameters of producer price.

To obtain consistent estimates we have to assume that under multi-stage budgeting the direct utility function is weakly separable. This approach implies that goods can be divided into a number of separate groups, where a change of the price of a good in one group affects the demand for all goods in another group in the same manner.

If we have a three-stage budgeting process, the first stage comprises of allocation between durables and non-durables goods. In the second stage, the household allocates its total expenditure between $n$ groups of goods. In the third stage, the household allocates its expenditure between $m$ goods within each of the $n$ groups. Given this structure, the Linear Ideal Demand System (LAIDS) model can be written in stochastic form as:

$$
\begin{aligned}
& w_{(r) t}=\alpha_{(r)}+\sum_{s=1}^{n} \gamma_{(r)(s)} \ln \bar{p}_{(s) t}+\sum_{s=1} \tilde{\gamma}_{i j} \ln \tau_{(r)(s)}+\beta_{(r)}\left(\ln x_{t}-\ln P_{t}\right)+\varepsilon_{(r) t} \\
& w_{(r) i t}=\alpha_{(r) i}+\sum_{s=1}^{n} \gamma_{(r) i j} \ln \bar{p}_{(r) i t}+\sum_{s=1} \tilde{\gamma}_{i j} \ln \tau_{(r) j t}+\beta_{(r)_{i}}\left(\ln x_{(r)_{t}}-\ln p_{(r)_{t}}\right)+\varepsilon_{(r)_{i t}}
\end{aligned}
$$

where $r=1, \ldots, n$ denotes group, $i=1, \ldots, m(r)$ denotes commodities within group $r$, and $t=1, \ldots, T$ denotes time period. Equation (6) thus describes the allocation between groups, where $w_{(r) t}$ denotes the budget share for good $r$ in period $t, \bar{p}_{(r) t}$ is a group 
producer price index, $x_{t}$ is total expenditure on non-durables, $\tau_{(r) t}$ is the group energy taxation index, and $P_{t}$ finally is the consumer price index for non-durables. Equation (7) describes allocation within the $r$ th group, where $w_{(r) i t}$ is the within group budget share, $\ln \bar{p}_{(r) j}$ is the producer price index of the $j$ th good, $x_{(r) t}$ is the total expenditure allocated to the $r$ th group, $\tau_{(r) j t}$ is the energy taxation index of goods $j$ within group $r$, and $p_{(r) t}$ is the stone price index for the $r$ th group.

Given estimates of the parameters at each "level", we can calculate price and expenditure elasticities, totally and conditional on the expenditures for each group (Edgerton et al. 1996) $)^{3}$. Using the main group notation the expenditure and uncompensated price elasticities are;

$$
\begin{aligned}
& E_{r}=1+\frac{\beta_{r}}{w_{r}}, \quad r=1, \ldots, n \\
& e_{r s}=\left(\frac{\gamma_{r s}-\beta_{r} w_{s}}{w_{r}}-\delta_{r s}\right), \quad r=1, \ldots, n, s=1, \ldots, n \\
& \tilde{e}_{r s}=\left(\frac{\tilde{\gamma}_{r s}-\beta_{r} w_{s}}{w_{r}}-\delta_{r s}\right), \quad r=1, \ldots, n, s=1, \ldots, n
\end{aligned}
$$

where $E_{r}$ denotes the expenditure elasticity for group $r, e_{r s}$ the uncompensated producer price elasticity, and $\tilde{e}_{r s}$ the uncompensated energy taxation elasticity, $\delta_{r s}$ equals one when $r=s$, and zero otherwise.

Let us denote the expenditure elasticity for the $i$ th good within the $r$ th group of goods as $E_{(r) i}$. The group expenditure elasticity for the $r$ th group of goods as $E_{(r)}$, and the total expenditure elasticity for the $i$ th good within the $r$ th group of goods, $E_{i}$, is then defined as :

$$
E_{i}=E_{(r)} E_{(r) i}
$$

In the same way, we can denote the within group price elasticity between the $i$ th and $j$ th goods within the $r$ th group of goods as $e_{(r) i j}$, the group price elasticity as $e_{(r)(s)}$ and the

\footnotetext{
${ }^{3}$ The model is estimated without any homogeneity, and symmetry restrictions.
} 
total price elasticties as $e_{i j}$. We can notice that the within group price elasticity assumes that group expenditure is unchanged in spite of the price change, whilst the total price elasticity allows for the relevant changes in group expenditure.

Finally we can denote the equivalent total price elasticity as

$$
e_{i j}=\delta_{r s} e_{(r) i j}+E_{(r) i} w_{(s) j}\left(\delta_{r s}+e_{(r)(s)}\right)
$$

If we look at equation (12) for two goods within the same group, we can see that the total price elasticity consists of two components. The first part is a direct effect, which represents the subgroup elasticity, while the second part is an indirect effect, which is a product of three factors. The first measure the relative change in the group price index when the price of the $j$ th good change (this is equal to $w_{(r) j}$ ), the second factor measures the effect a change in the price index has on the group expenditure $\left(1+e_{(r)(s)}\right)$, while the third factor measures the effect this change in within group expenditure has on the consumption of the $i$ th good $\left(E_{(r) i}\right)$.

We can also notice that if the own between group price elasticity $e_{(r)(r)}=-1$, then the group expenditure is unaffected by the price change and $e_{i j}=e_{(r) i j}$. On the other hand, if $e_{(r)(r)}=0$, then the price change produce a proportional effect on the group expenditure.

The model specified above will be estimated using time series data on Swedish consumption of non-durable goods from 1980 to 2002. Energy tax data are then linked to each type of good within the heating and transportation group.

Since the data spans over a relative long period we conduct tests of structural stability of the demand system for the entire sample period. The usual practice in assessing the constancy of regression coefficients over time it is to use prior information concerning the true point of structural change in the nature of regression relationship. The researcher identifies an event that is hypothesized to cause structural change, estimates separate regression, and examines whether the multiple sets of estimated coefficients are 
significantly different from each other using an F-test. This is the so-called Chow test. An alternative procedure is to estimate the model over the full sample period with one or more dummy variables. One drawback of Chow tests is the maintained assumption that the sample variances are equal in both time periods. An alternative, suggested by Hansen (1992), is the Wald test that does not impose this restriction.

It is important to note that both of these approaches require prior information regarding the event that is alleged to cause the structural change. One approach which does not require prior information concerning the true point of structural change is to conduct a series of Chow tests for each time period. An attractive property of these 1-step Chow tests is that they allow the data to identify when the true point of structural change occurs. A related approach is that of Brown, Durbin, and Evans (1975) (CUSUMSQ test). In this case, an analysis of the cumulative sum of squared residuals from the regression determines, if at all, structural (break) or shift occurs. These tests have been employed on time series data to analyse the demand for money (see Heller and Khan 1979), and aggregate output fluctuations (see McConnel and Perez-Quiros, 2000). In our context, we will use CUSUM and CUSUMSQ tests and the null hypothesis of these tests is that the demand system coefficients are constant over the time period.

\section{Description of the data}

The data set employed consist of aggregate time series over Swedish consumption of non-durable goods, and energy taxes linked to each type of good within the heating and transportation group covering the years 1980-2002. Our demand system is composed of expenditure on the following four main consumption groups; Foodstuff, transports, heating, and other goods. Expenditures on each of these groups are divided into individual goods as follows:

1. Foodstuff: expenditure on food and beverages.

2. Transport: expenditure on petrol, car maintenance, and public and other transport.

3. Heating: expenditure on electricity, district heating, and oil. 
4. Other goods: expenditure on clothes, health care, recreation, domestic appliances and other.

The estimation of household demand for the main groups (equations (6)) requires the following prices: general price index $\left(P_{t}\right)$, producer price index for each group $\left(\bar{p}_{(s) t}\right)$, and a energy tax index $\left(\tau_{(r)(s)}\right)$ for heating and transportation. The general price index is calculated using equation (2). The energy tax index for heating is defined as:

$$
\ln \left(\tau_{h e}\right)=w_{e l} \ln \left(\tau_{e l}\right)+w_{d i s} \ln \left(\tau_{d i s}\right)+w_{o i l} \ln \left(\tau_{o i l}\right),
$$

where $w_{e l}, w_{\text {dis }}$, and $w_{\text {oil }}$ are weights representing the budget share for electricity, district heating, and oil. The energy tax index for transportation is defined in a similar way, where $w_{p e}$, and $w_{p u b}$ are the budget share for petrol and public and other transport. Information on all the necessary weights is available from our data. Finally, we can use equation (3) to calculate the producer price index for the heating and transportation groups since we have consumer price indexes from our data and energy tax indexes as described above.

Figures 2, 3, and 4 contain summary statistics for the consumption data for the four main groups, and for the individual types of energy goods.

As can be seen in Figure 2 consumption of "transports" and "heating", measured as expenditure shares, have been fairly stable over the period, although there is a weak positive trend in the heating share. The "food" share, however, has decreased strongly, whereas “other goods” has increased. Since income has increased over this time period, the pattern in Figure 2 indicates that "food" is a necessary good, whereas "other goods" is a luxury. ${ }^{4}$ In Figure 4 we see that about 85 percent of total household expenditure on heating during the sample period is used on electricity and oil. Furthermore it can be seen that there has been a substantial substitution from the use of oil towards electricity during the same period.

\footnotetext{
${ }^{4}$ This conjecture is of course conditioned on unchanged relative prices.
} 


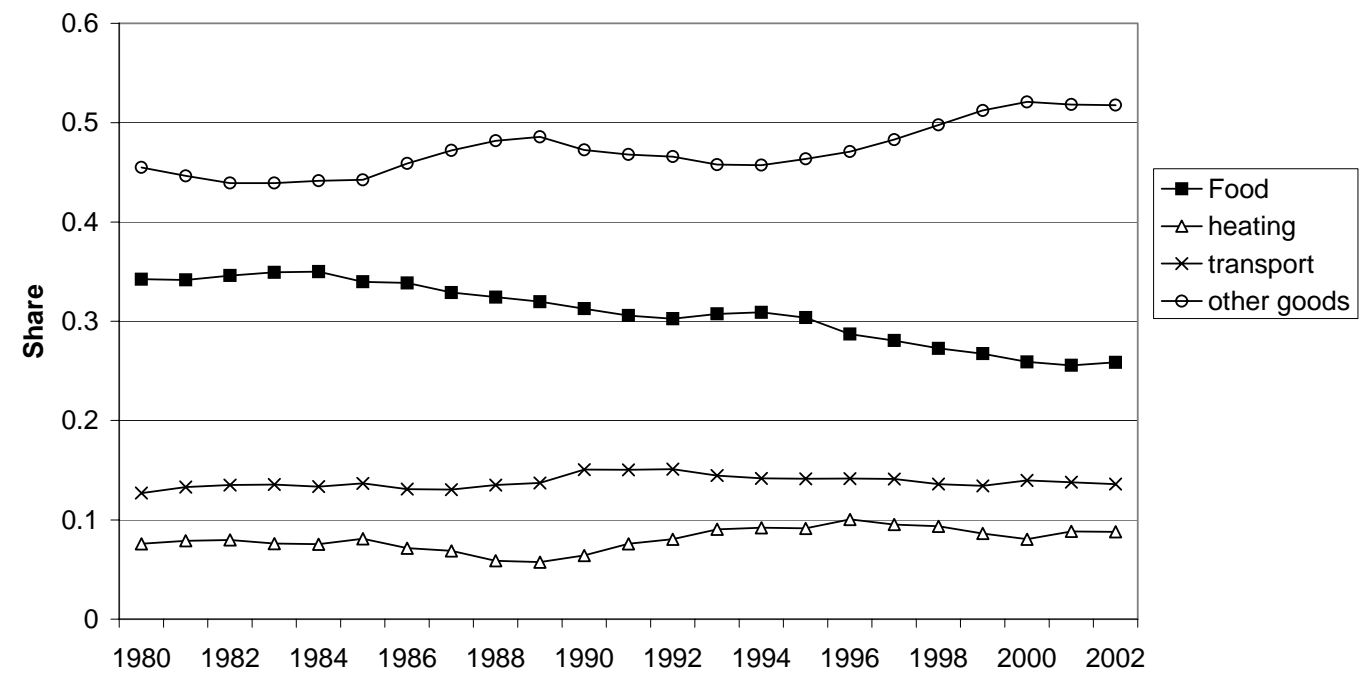

Figure 2. Expenditure shares, main groups.

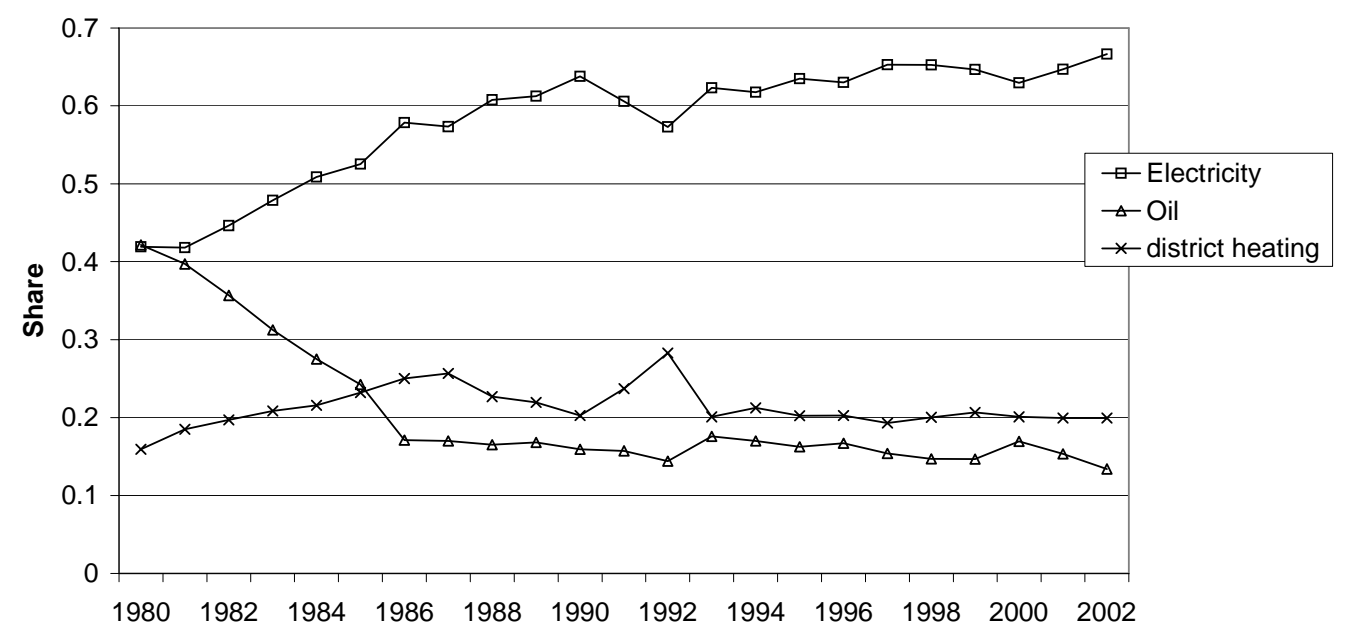

Figure 3. Expenditure shares, within heating group.

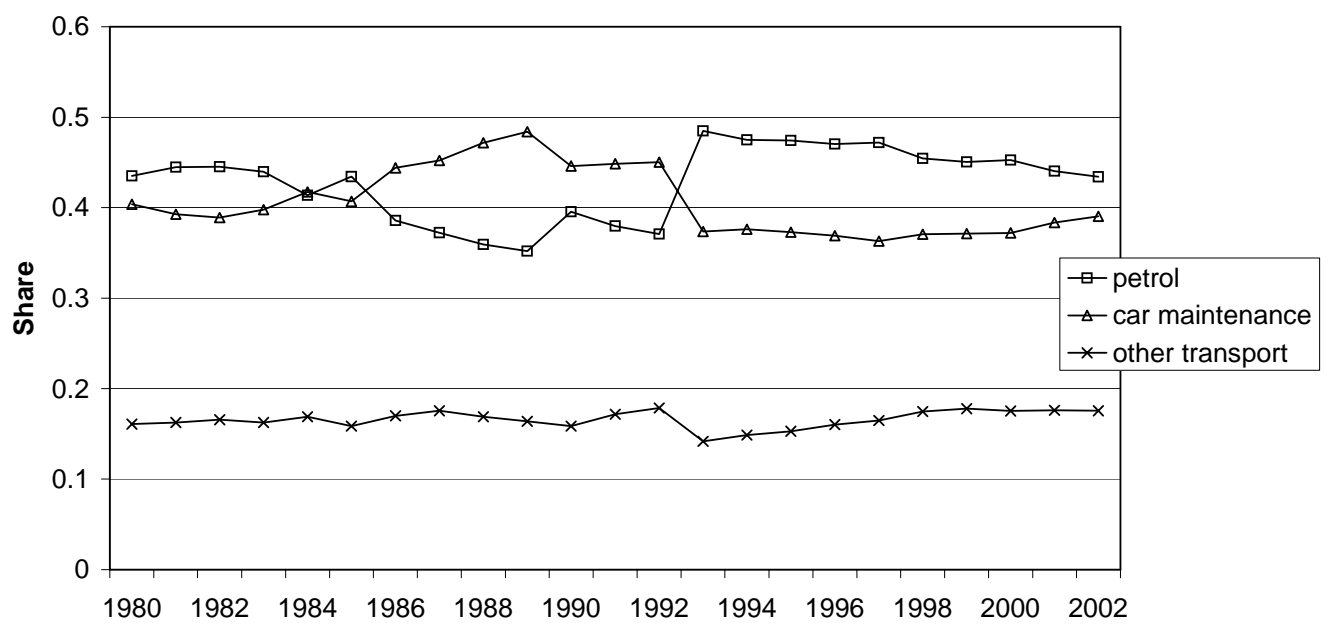

Figure 4. Expenditure shares, within transportation group. 


\section{Estimation and empirical results}

Following the specification in equations (6) and (7), the demand system for the main groups and for the goods within the main groups is estimated by OLS. Table A1-A5 in the Appendix, gives the estimates of the parameters of the model. The results indicate that most of the estimated parameters are significantly different from zero, and that the degree of explanation is good.

Based on the results from Tables A1-A5, we try to address two issues before calculating the own-price and expenditure elasticities. The first is to test if the parameters that represent the producer price and energy taxation are equal or not. The result from this test is presented in Table 1. According to the results, the null hypothesis of equality between the producer price and energy tax is rejected for every energy good except for the transport group and oil. ${ }^{5}$

Table 1. F-test of parameter equality.

\begin{tabular}{lll}
\hline Goods & F-test & $\begin{array}{l}\text { The null hypothesis : } \\
\gamma_{i j}=\bar{\gamma}_{i j}\end{array}$ \\
\hline Heating & $13.5^{*}$ & Reject \\
Transport & 0.49 & Do not reject \\
Petrol & $7.4^{*}$ & Reject \\
Other transportation & $52.5^{*}$ & Reject \\
Electricity & $31.8^{*}$ & Reject \\
District Heating & $52.8^{*}$ & Reject \\
Oil & 0.65 & Do not reject \\
\hline
\end{tabular}

Note: * significant at the $5 \%$ level.

The second issue is related to parameter stability in the demand system. If the model is unstable it will be difficult to interpret the regression results. Since a parametric econometric model is completely described by its parameters, model stability is equivalent to parameter stability (see Chan and Lee, 1997). We rely on the CUSUM and

\footnotetext{
${ }^{5}$ To calculate the F-test, we first estimate the unrestricted model (equation (6) for the main groups, or equation (7) for the goods within the main groups). In the estimation of the restricted model we include an equality constraint on the own-price parameter and the own-tax parameter, i.e. there is one restriction in each equation.
} 
CUSUMSQ tests of Brown et al. (1975). The tests are applied to the residuals of each main group in equation (6). The CUSUM test is based on the cumulative sum of recursive residuals. It is updated recursively and is plotted against the time. If the plot of CUSUM statistic stays within 5\% significance level (portrayed by two straight lines whose equations are given in Brown et al., 1975), then coefficient estimates are said to be stable. A similar procedure is used to carry out the CUSUMSQ which is based on the squared recursive residuals. In general, if the CUSUM or CUSUMSQ move outside the critical lines of $5 \%$ significance level, the null hypothesis will be rejected, meaning that the model is unstable.

As can be seen from Appendix B, the plot of CUSUM statistic stays within the critical lines indicating stability in demand model. On the other hand, the plot of CUSUMSQ test moves outside the critical lines of $5 \%$ significance level in the transport and other goods groups but remain within the critical lines of $10 \%$ significance level. Accordingly, there is evidence supporting a stability hypothesis of the demand system..

Now we can use the estimated parameters to calculate the elasticities. These elasticities depend on the values of prices, energy taxes and total expenditure at which they are evaluated. Here we evaluate the elasticities at the sample mean for the period 19802002. Given the estimated parameters, the expenditure and price elasticities can be calculated according to (8), (9), (10), (11), and (12). The resulting elasticities are presented in Table 2. 
Table 2. Estimated own price and expenditure elasticities.

\begin{tabular}{|c|c|c|c|c|}
\hline & Own-Price & Expenditure & $\begin{array}{l}\text { Total own- } \\
\text { price }\end{array}$ & $\begin{array}{l}\text { Total } \\
\text { expenditure }\end{array}$ \\
\hline \multicolumn{5}{|c|}{ MAIN GROUPS } \\
\hline Foodstuff & -0.11 & 0.26 & & \\
\hline Heating & -0.07 & 0.61 & & \\
\hline Heating tax & $-0.36^{*}$ & & & \\
\hline Transport & -0.17 & 0.53 & & \\
\hline Transport tax & -0.20 & & & \\
\hline Other goods & -0.84 & 1.50 & & \\
\hline \multicolumn{5}{|c|}{ FOODSTUFF } \\
\hline Food & -0.78 & 0.79 & -0.31 & 0.21 \\
\hline Beverages & -0.98 & 1.43 & -0.57 & 0.38 \\
\hline \multicolumn{5}{|c|}{ HEATING } \\
\hline Electricity & -0.61 & 0.75 & -0.14 & 0.46 \\
\hline Electricity tax & $-1.80^{*}$ & & -1.40 & \\
\hline District heating & -0.43 & 1.92 & -0.08 & 1.18 \\
\hline District heating tax & $-1.83^{*}$ & & -1.59 & \\
\hline Oil & -0.99 & 1.04 & -0.86 & 0.64 \\
\hline Oil tax & $-1.58^{*}$ & & -1.49 & \\
\hline \multicolumn{5}{|c|}{ TRANSPORTS } \\
\hline Petrol & -0.71 & 0.72 & -0.45 & 0.32 \\
\hline Petrol tax & -0.46 & & -0.21 & \\
\hline Car maintenance & -0.99 & 1.53 & -0.49 & 0.82 \\
\hline Public and other transp & -0.55 & 0.49 & -0.47 & 0.26 \\
\hline Public and other transp tax & -0.76 & & -0.69 & \\
\hline \multicolumn{5}{|c|}{ OTHER } \\
\hline Clothes & -1.29 & 0.72 & -1.27 & 1.12 \\
\hline Other goods & -0.81 & 1.03 & -0.73 & 1.60 \\
\hline Health care & -0.23 & 0.64 & -0.23 & 0.90 \\
\hline Recreation & -0.87 & 1.33 & -0.84 & 2.06 \\
\hline Domestic appl. & -1.58 & 1.05 & -1.56 & 1.60 \\
\hline
\end{tabular}

Note: ${ }^{*}$ the signalling effect is significant.

From Table 2 we can notice that all expenditure and own-price elasticities have the expected signs. The expenditure elasticities indicate that food, heating and transportation are necessities, whereas other goods are luxuries. All own-price elasticities have a negative sign, meaning that a price increase will reduce demand for that good.

Table 2 should be read in the following way. If the price of electricity increases by $10 \%$, the demand for electricity decreases by $6.1 \%$. But if the energy tax for electricity 
increases by $10 \%$, the demand for electricity is reduced by $18 \%$. In other words, the energy tax for electricity has larger impact on consumer demand than the producer price of electricity.

From this point of view, we can notice that Swedish consumers are more sensitive to energy taxes than producer price for most energy goods except petrol and public and other transport. It seems that a change in energy taxes for these goods have a smaller impact than a change in producer price for these goods. It should be noted that most of the own price elasticities are between 0 and -1 , which implies that a higher price of one good increase its budget share in spite of lower consumption of that good.

Also from Table 2, the total expenditure elasticities indicate that all goods in the within food, heating and transportation are necessities, i.e. these have total expenditure elasticities less than one. Within the "other goods" group, clothes, recreation, and domestic appliances are found to be luxuries, since they have total expenditure elasticities that are larger than one.

Furthermore, the results in Table 2, show that the tax elasticities seem to be -in absolute value- higher than -1 for electricity, oil, and district heating. For these goods, higher energy taxes will lead to a relatively large reduction in consumption, but also a decrease in the budget share. From this point of view, we can say that the energy taxes may be efficient if the objective is to reduce emissions, but inefficient if the objective with the tax is strictly fiscal. On the other hand, the tax elasticities for petrol and public and other transport is less than -1 , meaning that if the tax increases on these goods, energy taxes will be more efficient from a fiscal point of view, at least in the short run.

\section{Conclusion and discussion}

One of the key issues in public policy in general, and perhaps in environmental policy in particular, is how consumers respond to changes in policy. In this paper the issue is how consumers respond to changes in taxation, in particular environmental taxation. The basic question posed is if the response to a price change depends on the source of the price change. The idea is to test if changes in the consumer price that results from the introduction, or change, in environmental taxes give a different signal to the 
consumer, compared with changes in the consumer price that results only from a producer price change.

To achieve the objectives a system of demand functions for Swedish households is estimated. To test for the signalling effect of environmental taxes the consumer price for energy goods is partitioned into a producer price part and a tax part. The results of the study show that changes in environmental taxes has a significant signalling effect on the demand for residential heating in the sense that the consumers are more sensitive to a tax change than a producer price change. For transports, however, the results show no significant difference. Concerning individual commodities within the main groups the results shows that the tax elasticity is higher (in absolute value) for all types of energy within heating (electricity, oil, district heating). Within transports, however, the results indicate the opposite, i.e. petrol consumption seems to be less sensitive to a tax change than to a change in the producer price. These results are then indicating that environmental policy, in the form of energy taxes, will be more effective in reducing pollution due to consumption of heating, but less effective in reducing pollution from transports.

In this paper we use macro level time-series data for Swedish household expenditure. This may be one explanation to the somewhat ambiguous results concerning the signalling effect, i.e. we have not been able to control for long-run trends in petrol consumption affected by for example improvements in fuel efficiency. Furthermore, the aggregate nature of the data may be another explanation. It may be the case that there are large differences between different types of households, depending on family size, income level, place of residence, etc., which is not captured using macro data. Thus, using panel data to determine the difference in signalling effect at the specific level of household may be a better way to investigate this matter. Furthermore, one could also examine the effect of the "consistency" of environmental policy by estimating the above model for the first major introduction of the environmental tax, compared with the subsequent increases of the same tax. It may be the case that the signalling effect is "non-linear" in the sense that the signalling effect is stronger when the tax is introduced than for subsequent changes of the tax. However, this will be subject for future research. 


\section{References}

Agnolucci, P. (2004). Ex Post Evaluation of $\mathrm{CO}_{2}$ - Based Taxes: A Survey. Tyndall Centre for Climate Change Research, Working Paper 52, London.

Barigozzi, F., Villeneuve, B. (2004). The Signaling Effect of Tax Policy, Working Paper 500, Department of Economics, University of Bologna.

Berkhout, H.G., Carbonell, F., and Muskens. C. (2004). The Ex Post Impact of an Energy Tax on Household Energy Demand. Journal of Energy Economics ,26 ,297-317.

Bovenberg, L. (1999). Green Tax Reforms and The Double Dividend: an Updataed Reader’s Guide. International Tax and Public Finance, 6,421-443.

Brännlund, R., Kriström, B. (1997). Energy and Environmental Taxation in Sweden: Some Experience from the Swedish Green Tax. "Invited paper" Environmental Implications of Market Based policy Instruments” Gothenburg, Sweden.

Brännlund, R., Ghalwash, T. and Nordström, J. (2004). Increased Energy Efficiency and The Rebound Effect: Effects on Consumption and Emissions. Umeå Economic Studies, No.642, Umeå University, Sweden.

Brännlund, R., Nordström, J. (2004). Carbon Tax Simulation Using a Household Demand Model. European Economic Review, 48, 211-233.

Brown, R. L., Durbin, J., and Evans, J. M. (1975). Techniques for Testing The Constancy of Regression Relationships Over Time, Journal of the Royal Statistical Society, (37), (3), 149-163.

Deaton, A., Muellbauer, J. (1980). An Almost Ideal Demand System, The American Economic Review, 7, 312-326.

Edgerton, D. L., Assarsson, B., Hummelmose, A., Laurila, I. P., Rickertsen, K. and Vale, P. H. (1996). The Econometrics of Demand Systems: With Applications to Food Demand in the Nordic Countries, Kluwer Academic Publishers, Boston. 
Garcia-Cerruti, L. M. (2000). Estimating Elasticities of Residential Energy Demand from Panel County Data Using Dynamic Random Variables Models with Heteroskedastic and Correlated Error Terms. Resource and Energy Economics 22, 335366.

Halvorsen, B., Larsen, B.M. (2001). The Flexibility of Household Electricity Demand over Time. Resource and Energy Economics 23, 1-18.

Hansen, Bruce. (1992), Testing for Parameter Instability in Linear Models, Journal of Policy Modelling, 14, 517-533.

Heller, R. H., Moshin. S.K. (1979), The Demand for Money and The Term Structure of Interest Rates, Journal of Political Economy, 87, 109-129.

McConnell, M. M., G Perez-Quiros. (2000), Output Fluctuations in the United States: what has changed since the early 1980's?, American Economic Review, 90, 1464-1467.

Paton, D., Siegel, D., and Williams, L.V. (2001). A Time Series Analysis of the Demand for Gambling in the United Kingdom. Nottingham University Business School Discussion Paper, Nottingham University Business School.

Schöb, R. (2003), The Double Dividend Hypothesis of Environmental Taxes: A Survey, Faculty of Economics and Management, Working Paper 4, Otto-von-GuerickeUniversity Magdeburg, March, Germany. 


\section{Appendix A}

Table A1: Demand system parameter Estimates for the period 1980-2002 in the main group.

\begin{tabular}{lllllllll}
\hline & constant & $\begin{array}{l}\text { Price of } \\
\text { food }\end{array}$ & $\begin{array}{l}\text { Price of } \\
\text { heating }\end{array}$ & $\begin{array}{l}\text { Heating } \\
\text { tax }\end{array}$ & $\begin{array}{l}\text { price of } \\
\text { transport }\end{array}$ & $\begin{array}{l}\text { Transport } \\
\text { tax }\end{array}$ & $\begin{array}{l}\text { Price of } \\
\text { other } \\
\text { goods }\end{array}$ & $\begin{array}{l}\text { Expenditure } \\
\text { coefficient }\end{array}$ \\
\hline Food & 1.6 & 0.17 & -0.004 & -0.01 & 0.007 & 0.006 & -0.18 & -0.18 \\
& $(16.4)$ & $(7.9)$ & $(-0.29)$ & $(-1.2)$ & $(0.31)$ & $(0.3)$ & $(-6.1)$ & $(-12.7)$ \\
Heating & 0.23 & -0.03 & 0.07 & 0.05 & -0.03 & 0.002 & 0.02 & -0.03 \\
& $(1.5)$ & $(-0.85)$ & $(3.9)$ & $(2.6)$ & $(-1.2)$ & $(0.06)$ & $(0.6)$ & $(-1.6)$ \\
Transport & 0.5 & 0.01 & -0.03 & -0.2 & 0.01 & 0.09 & -0.07 & -0.06 \\
Other & $(4.9)$ & $(0.51)$ & $(-1.8)$ & $(-1.3)$ & $(4.4)$ & $(4.0)$ & $(-2.3)$ & $(-4.2)$ \\
goods & -1.4 & -0.14 & -0.05 & -0.02 & -0.06 & -0.09 & 0.22 & 0.28 \\
\hline
\end{tabular}

Table A2: Demand system parameter Estimates for the period 1980-2002 in the food subgroup.

\begin{tabular}{lllll}
\hline & constant & Price of food & Price of beverages & $\begin{array}{l}\text { Expenditure } \\
\text { coefficient }\end{array}$ \\
\hline Food & 1.5 & 0.05 & -0.05 & -0.13 \\
& $(10.4)$ & $(4.6)$ & $(-5.1)$ & $(-5.2)$ \\
Beverages & -0.54 & -0.5 & 0.05 & -0.13 \\
& $(-3.7)$ & $(-4.6)$ & $(5.2)$ & $(-5.2)$ \\
\hline
\end{tabular}

Table A3: Demand system parameter Estimates for the period 1980-2002 in the heating subgroup.

\begin{tabular}{llllllllll}
\hline & constant & $\begin{array}{l}\text { Price of } \\
\text { Electricity }\end{array}$ & $\begin{array}{l}\text { Electricity } \\
\text { tax }\end{array}$ & $\begin{array}{l}\text { Price of } \\
\text { district } \\
\text { heating }\end{array}$ & $\begin{array}{l}\text { District } \\
\text { heating } \\
\text { tax }\end{array}$ & $\begin{array}{l}\text { Price } \\
\text { of oil }\end{array}$ & $\begin{array}{l}\text { Oil } \\
\text { taxation }\end{array}$ & $\begin{array}{l}\text { Expenditure } \\
\text { coefficient }\end{array}$ \\
\hline Electricity & 2.7 & 0.14 & -0.64 & -0.07 & 0.19 & 0.8 & 0.17 & -0.16 \\
District & $(7.5)$ & $(2.4)$ & $(-4.5)$ & $(-1.5)$ & $(2.2)$ & $(1.7)$ & $(1.3)$ & $(-3.1)$ \\
Heating & -2.5 & -0.11 & 0.2 & 0.14 & -0.13 & 0.08 & 0.38 & 0.18 \\
Oil & $(-10.9)$ & $(-2.6)$ & $(3.2)$ & $(4.6)$ & $(-2.3)$ & $(2.5)$ & $(4.4)$ & $(5.4)$ & \\
& 1.1 & -0.16 & -0.03 & -0.14 & -0.12 & 0.002 & -0.07 & 0.006 \\
& $(3.2)$ & $(-2.5)$ & $(-0.2)$ & $(-3.1)$ & $(-1.5)$ & $(0.04)$ & $(-0.54)$ & $(0.16)$ \\
\hline
\end{tabular}

Table A4: Demand system parameter Estimates for the period 1980-2002 in the Transport subgroup.

\begin{tabular}{llllllll}
\hline & constant & $\begin{array}{l}\text { Price } \\
\text { of } \\
\text { petrol }\end{array}$ & $\begin{array}{l}\text { Petrol } \\
\text { tax }\end{array}$ & $\begin{array}{l}\text { Price of car } \\
\text { maintenance }\end{array}$ & $\begin{array}{l}\text { Price of } \\
\text { public and } \\
\text { other } \\
\text { transport }\end{array}$ & $\begin{array}{l}\text { Public and } \\
\text { other } \\
\text { transport } \\
\text { tax }\end{array}$ & $\begin{array}{l}\text { Expenditure } \\
\text { coefficient }\end{array}$ \\
\hline petrol & 0.9 & 0.06 & 0.18 & 0.01 & -0.02 & -0.11 & -0.16 \\
car & $(3.9)$ & $(1.4)$ & $(2.3)$ & $(0.29)$ & $(-0.40)$ & $(-2.2)$ & $(-3.9)$ \\
maintenance & -0.69 & -0.11 & -0.18 & 0.08 & -0.02 & 0.004 & 0.21 \\
$\begin{array}{l}\text { Public and } \\
\text { other }\end{array}$ & 0.88 & $(-2.6)$ & $(-2.4)$ & $(1.8)$ & $(-0.37)$ & $(0.09)$ & $(4.5)$ \\
transport & $(8.1)$ & $(2.04$ & 0.0001 & -0.09 & 0.06 & 0.12 & -0.08 \\
\hline
\end{tabular}


Table A5: Demand system parameter Estimates for the period 1980-2002 in the Other goods subgroup.

\begin{tabular}{llllllll}
\hline & constant & $\begin{array}{l}\text { Price of } \\
\text { clothes }\end{array}$ & $\begin{array}{l}\text { Price } \\
\text { of } \\
\text { other } \\
\text { goods }\end{array}$ & $\begin{array}{l}\text { Price of } \\
\text { health } \\
\text { care }\end{array}$ & $\begin{array}{l}\text { Price of } \\
\text { recreation }\end{array}$ & $\begin{array}{l}\text { Price of } \\
\text { Domestic } \\
\text { appliances }\end{array}$ & $\begin{array}{l}\text { Expenditure } \\
\text { coefficient }\end{array}$ \\
\hline Clothes & 1.1 & -0.05 & -0.18 & -0.03 & 0.17 & -0.01 & -0.04 \\
other goods & $(4.80)$ & $(-1.5)$ & $(-4.2)$ & $(-1.7)$ & $(4.1)$ & $(-0.2)$ & $(-2.9)$ \\
& -0.14 & 0.007 & 0.09 & 0.06 & -0.18 & 0.1 & 0.02 \\
Health care & $(-0.68)$ & $(0.2)$ & $(2.4)$ & $(2.9)$ & $(-4.4)$ & $(1.4)$ & $(1.07)$ \\
& 0.22 & -0.009 & 0.007 & 0.05 & -0.01 & -0.03 & -0.02 \\
Recreation & $(2.7)$ & $(-0.64)$ & $(0.5)$ & $(7.1)$ & $(-0.79)$ & $(-1.4)$ & $(-4.8)$ \\
& -0.59 & 0.02 & 0.06 & -0.04 & 0.03 & 0.02 & 0.05 \\
Domestic & $(-3.0)$ & $(0.44)$ & $(1.7)$ & $(-2.4)$ & $(0.67)$ & $(0.36)$ & $(3.6)$ \\
appliances & $(3.1)$ & 0.04 & 0.009 & -0.03 & -0.007 & -0.7 & 0.007 \\
\hline
\end{tabular}

Note. $t$ value are presented in the parenthesis. 


\section{Appendix B}
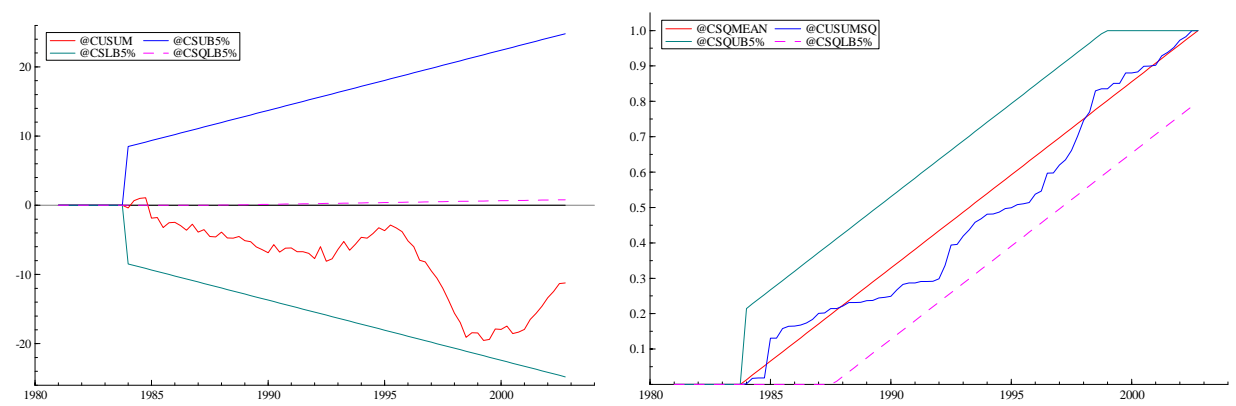

The straight lines represent critical bounds at 5\% significance level Figure B-1 : Cusum and Cusumsq test for food group.
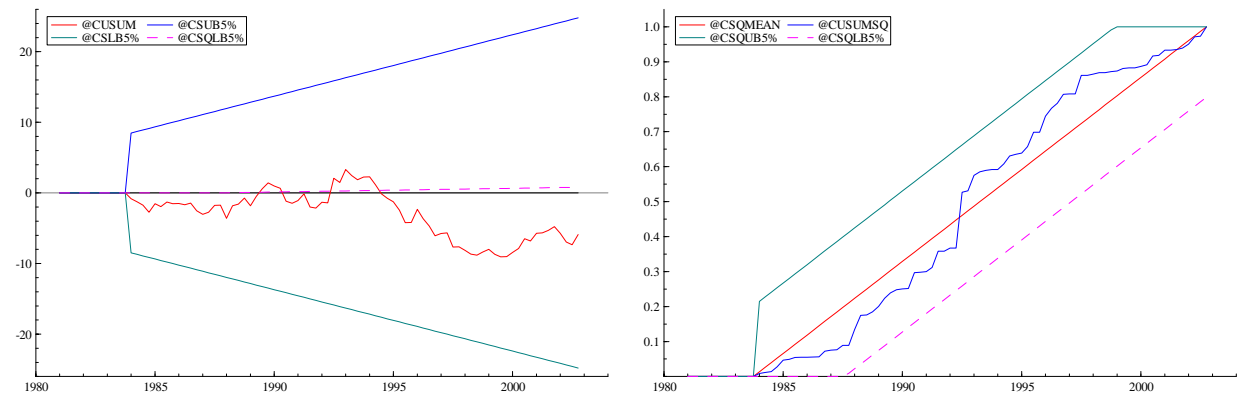

The straight lines represent critical bounds at 5\% significance level Figure B-2: Cusum and Cusumsq test for heating group
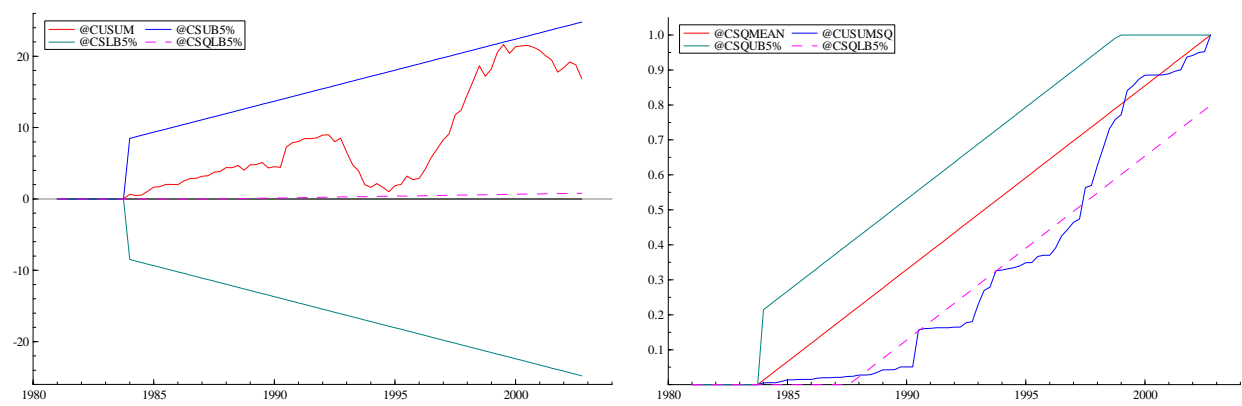

The straight lines represent critical bounds at 5\% significance level Figure B-3: Cusum and Cusumsq test for transport group 

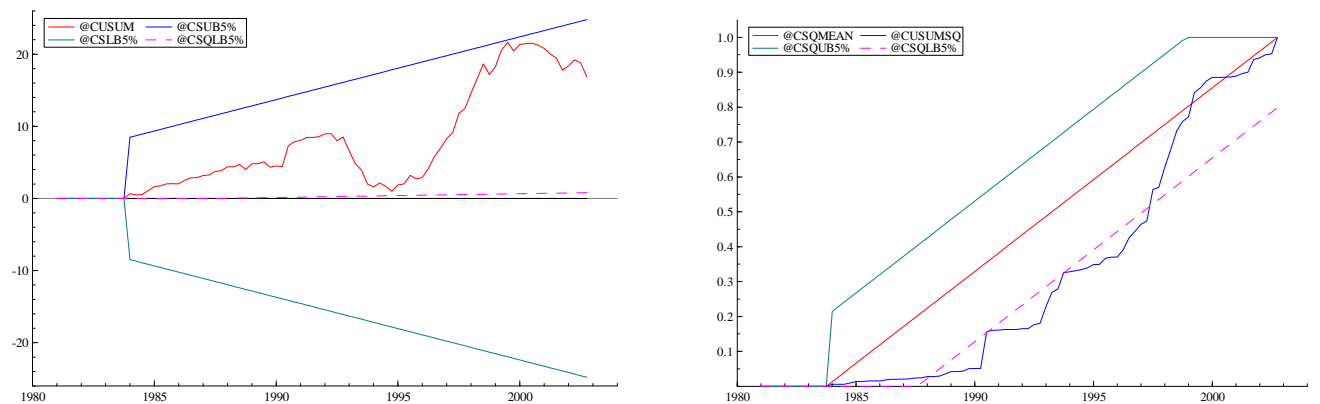

The straight lines represent critical bounds at 5\% significance level

Figure B-4: Cusum and Cusumsq test for other goods 